\title{
Article
}

\section{Continuing professional development in numeracy skills for non-medical prescribers}

Broadhead, Ruth

Available at http://clok.uclan.ac.uk/28307/

Broadhead, Ruth (2019) Continuing professional development in numeracy skills for non-medical prescribers. Journal of Prescribing Practice, 1 (4). pp. 174-175. ISSN 2631-8385

It is advisable to refer to the publisher's version if you intend to cite from the work. 10.12968/jprp.2019.1.4.174

For more information about UCLan's research in this area go to http://www.uclan.ac.uk/researchgroups/ and search for < name of research Group>.

For information about Research generally at UCLan please go to http://www.uclan.ac.uk/research/

All outputs in CLoK are protected by Intellectual Property Rights law, including Copyright law. Copyright, IPR and Moral Rights for the works on this site are retained by the individual authors and/or other copyright owners. Terms and conditions for use of this material are defined in the policies page.

\section{CLoK}

Central Lancashire online Knowledge www.clok.uclan.ac.uk

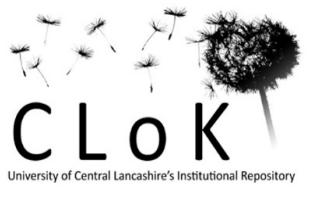




\section{Calculation Skills}

\section{Continuous Professional Development in Numeracy Skills for Non-Medical Prescribers}

Within their codes and prescribing standards, the Nursing and Midwifery Council $(2015 ; 2018)$, the General Pharmaceutical Council $(2017 ; 2019)$ and the Health and Care Professions Council $(2013 ; 2016)$ all mandate that continuous professional development is essential for maintaining safety and credibility as prescribing practitioners. Whilst Non-Medical Prescribing students enter their programme of study with a minimum level of numeracy as a pre-requisite, these skills are further enhanced, developed and assessed during the programme, but this skill should then form a customary component of professional development once qualified.

With the implementation of $A$ competency framework for all prescribers (The Royal Pharmaceutical Society (RPS), 2016, pg.8), prescribers are required to 'take responsibility for their own learning and continuing professional development'. Both domains of the framework, The Consultation and Prescribing Governance incorporate competencies that require that high standards of numeracy and calculation skills are sustained. Competency 4.6 specifically states that the prescriber should "Accurately complete and routinely check calculations relevant to prescribing and practical dosing", yet other competencies, although more implicitly, require that numeracy skills are integral to the prescriber's proficiency in order to meet them. In supporting the prescriber to maintain these skills, the following practise calculations may assist.

\section{Question 1:}

The British Medical Association \& Royal Pharmaceutical Society (2018) state that ready-prepared infusions should be used whenever possible and advise that preparations can be given by continuous infusion; intermittent infusion and addition via the drip tubing.

Patient A is admitted to the Medical Assessment Unit with acute abdominal pain. Prior to surgical intervention, the patient is nil by mouth and is hydrated with continuous intravenous fluids using the following regime:

- Sodium chloride $0.9 \% \times 1$ litre over 4 hours

- Glucose $5 \%$ / Sodium chloride $0.9 \%$ x 1 litre over 4 hours

- Sodium chloride $0.9 \% \times 1$ litre over 8 hours

- Glucose $5 \%$ / Sodium chloride $0.9 \%$ x 1 litre over 8 hours

1a. What is the total volume infused over 24 hours?

1b. From day two, IV antibiotics are prescribed as an intermittent infusion four times a day. Each dose is mixed with $250 \mathrm{ml}$ normal saline for infusion over 15 minutes. What is the total additional fluid volume per day? 
1c. From day two, what is the total volume infused over 24 hours?

\section{Question 2.}

Patient B attends the community pharmacy with an FP10 prescription from their prescribing nurse. The prescription states:

- Drug Y 250mg capsules

One capsule three times a day for 28 days

2a. How many capsules will be dispensed for 28 days' supply?

$2 \mathrm{~b}$. Following a months' trial of the medication, the nurse reviews the patients and a decision is made to continue the medication indefinitely. The dose is altered to one tablet daily. How many capsules will be required for 8 weeks' supply?

2c. The capsules are supplied in packs of 56 tablets. How many packs will be required by the patient over a 6 month period?

\section{Question 3.}

You are a paramedic prescriber working in the local walk-in centre. Baby Charlie is brought in by his mother with an infection. Antibiotics are required to treat the child. The BNF state that Antibiotic B should be prescribed three times a day for 3 days. One dose is $5 \mathrm{mg} / \mathrm{kg}$ and the baby weights $12 \mathrm{~kg}$. The strength of Antibiotic $B$ is $10 \mathrm{mg}$ per $10 \mathrm{ml}$.

3a. What amount in mg equates to one dose?

3b. How many mg per day will this baby require

3c. How many mls of Antibiotic B should be prescribed in total?

\section{Question 4.}

Wright, Scott and Buck et al (2019) identify reactive and proactive deprescribing as an essential part of a prescriber's remit. 'Reactive' deprescribing is defined as the cessation of medications that are already causing harm to the patient as opposed to 'proactive' deprescribing which is undertaken to prevent future harm to the recipient. There is a recognised list of drugs that are identified by Farrell et al (2015) as the main priorities for appropriate deprescribing. These include tricyclic antidepressants.

Alison has been taking a tricyclic antidepressant for 5 years and wants to stop her medication. The BNF advocates a reduction in her original dose by $25 \%$ per day every 4 weeks. The drug is currently prescribed at $20 \mathrm{mg}$ daily and Alison is prescribed $10 \mathrm{mg}$ tablets. The drug is available in $1 \mathrm{mg}, 2 \mathrm{mg}, 5 \mathrm{mg}, 10 \mathrm{mg}, 15 \mathrm{mg}$ tablets. 
4a. How many tablets does Alison currently take in one week?

4b. What dose of this drug will Alison take on weeks 1 to 4 ?

4b. What strength of drug will she take between weeks 9 to 12 ?

\section{Question 5.}

You are a supplementary prescriber using a clinical management plan. The clinical management plan has 10 different medications on it. One of these is paracetamol and another is ibuprofen. You wish to prescribe both of these to your patient concurrently for chronic pain. There are no contraindications or interactions.

The regime is as follows:

- Paracetamol 500mg tablets - 1 g every 6 hours $(0600 ; 1200 ; 1800 ; 1200)$

- Ibuprofen 400mg capsules x 2 capsules every 8 hours $(0600 ; 1400 ; 2200)$

5a. How many paracetamol tablets will you prescribe for 4 weeks' supply?

5b. How many ibuprofen capsules will your patient take over 7 days?

5c. How many tablets and capsules (in total) will your patient take at 0600 every day?

References:

British Medical Association \& Royal Pharmaceutical Society (2018) British National Formulary, Version 76. London: BMA \& RPS.

General Pharmaceutical Council (2017) Standards for pharmacy professionals. London: GPhC.

General Pharmaceutical Council (2019) Standards for the education and training of pharmacist independent prescribers. London: GPhC

Health and Care Professions Council (2013) Standards for Prescribing. London: $\mathrm{HCPC}$

Health and Care Professions Council (2016) Standards of conduct, performance and ethics. London: HCPC

Royal Pharmaceutical Society (2016) A competency framework for all prescribers. London. RPS

Wright, DJ., Scott, S., Buck, J., Bhattacharya, D. (2019) Role of nurses in supporting proactive deprescribing. Nursing Standard. Vol 34; No 3. Pp 44-49 


\section{Answers:}

1a. 4 litres

1b. 1 litre

1c. 5 litres

2a. 84 capsules

2b. 56 capsules

2c. 3 packs

3a. $60 \mathrm{mg}$

3b. $180 \mathrm{mg}$

3c. $540 \mathrm{mls}$

4a. $14 \times 10 \mathrm{mg}$ tablets

4b. $15 \mathrm{mg}$ daily

4c. $5 \mathrm{mg}$

5a. 224 tablets

5b. 42 capsules

5c. 4 in total ( $2 \times$ paracetamol tablets and $2 \times$ ibuprofen capsules) 